\title{
Our Magnetic Resonance Imaging Findings in Symptomatic Uterine Fibroid Patients Who Underwent Uterine Artery Embolization
}

\section{Uterin Arter Embolizasyon Tedavisi Yapılan Semptomatik Uterin Miyomu Olan Hasta Grubunda Klinik ve Manyetik Rezonans Görüntüleme Bulgularımız}

\author{
Caglayan Cakir ${ }^{\oplus}$, Fatih Kilinç®, Aysun Erbahceci Salik®, Hakan Selcuk $\odot$ \\ University of Health Sciences, Radiology Depertment of Bakirkoy Dr Sadi Konuk Training and Resarch Hospital, Istanbul, Turkey
}

Received: 11 September 2019 / Accepted: 13 January 2020 / Publication date: 26 June 2020

Cite as: Cakir C, Kilinç F, Erbahceci Salik A, Selcuk H. Our magnetic resonance imaging findings in symptomatic uterine fibroid patients who underwent uterine artery embolization. Med J Bakirkoy 2020;16(2):152-9.

\begin{abstract}
Objective: We aimed to examine the technical success, early-stage clinical results and radiological follow up findings of uterine artery embolization (UAE) treatment for symptomatic uterine fibroids in patients.

Method: In the present study, we retrospectively evaluated the patients who were admitted to our hospital. Between February 2017 and July 2019 with symptoms due to uterine fibroids namely myomas and underwent endovascular embolization treatment. Patients with complaints of excessive, prolonged, irregular, and frequent episodes of uterine bleeding, anemia, abdominal pain, palpable mass, and pollakiuria associated with uterine myoma which impaired quality life of the patients were included in this study. In addition, Magnetic Resonance Imaging (MRI) findings, and clinical symptoms of all patients before UAE, and 6th months after UAE were recorded.

Results: In our study, a total of 40 patients aged between 23-50 years (mean 41.3), one of whom had a history of hysterectomy underwent UAE procedure in our hospital. In our series, clinical symptoms, MRI and digital subtraction angiography (DSA) findings were presented. Uterine fibroid volumes as estimated based on MRI images obtained before - and 6 months after UAE were recorded $(234,47 \pm 76,48$ vs $17,27 \pm 43,53(p=0,001)$. Embolization was cancelled due to intense atherosclerotic causes in one patient, and embolization of unilateral uterine artery could be achieved. The remaining 39 patients underwent successful UAE procedure bilaterally. There were no complications associated with endovascular procedure. After the procedure, all of these 39 patients were discharged on the same day following bed rest and one patient could be discharged one week later due to the development of urosepsis.

Conclusion: UAE is a novel treatment modality which is being increasingly used in patients with symptomatic uterine fibroids, and it is an important and effective treatment option since it is much less invasive compared to hysterectomy, does not require hospitalization after the procedure and can be performed under simple sedation or spinal anesthesia.
\end{abstract}

Keywords: uterine fibroids, uterine artery, embolization, magnetic resonance imaging

öz

Amaç: Çalışmamızda miyom nedeniyle semptomları olan hasta grubunda Uterin Arter Embolizasyon (UAE) tedavisinin teknik başarı, erken dönem klinik sonuçları ve radyolojik takip bulgularını gözden geçirmeyi amaçladık.

Yöntem: Şubat 2017-Temmuz 2019 tarihleri arasında hastanemize uterin fibroide yani miyoma bağlı semptomları nedeniyle başvurup UAE tedavi isslemi uygulanan hastaları retrospektif olarak inceledik. Çalıșmaya yaşam kalitesini bozacak şekilde miyoma bağlı miktar olarak fazla, uzun süreli, sık ve düzensiz aralıklarla olan uterin kanamalar,anemi, karın ağrısı, ele gelen kitle ve sık idrara çıkma şikayetleri olan hastalar dahil edildi. Tüm hastalarda UAE öncesi ve UAE sonrası 6. ayda, manyetik rezonans görüntüleme (MRG) ile klinik semptomları kaydedildi.

Bulgular: Çalışmamızda uterin fibroide bağlı semptomları olan 23-50 yaş arası (ort. 41,3) daha önce bir tanesi histerektomi operasyonu geçirmiş olmak üzere toplam kırk hastaya UAE işlemi yapıldı. Serimizde hastaların klinik semptomları, MR ve dijital subtraksiyon anjiyografi (DSA) bulguları sunulmuştur. UAE öncesi ve 6. ayda total, MR Uterin fiboid hacmi; $234,47 \pm 76,48$ ve $117,27 \pm 43,53$ ( $p=0,001$ ) olup UAE öncesi ve 6. aydaki değerleri kayıt altına alındı. Bir hastada yoğun aterosklerotik sebeplerden dolayı işlem iptal edilmis olup tek taraflı uterin arter embolize edilebilmiştir. Otuz dokuz hastada çift taraflı olarak başarılı bir şekilde UAE işlemi uygulanmıştır. Hastalarda endovasküler işlemle ilişkili herhengi bir komplikasyon gelişmedi. Toplam 39 hasta işlemin ertesi günü yatak istirahatini takiben aynı gün taburcu edilmiş olup 1 hastada ürosepsis gelișmesi nedeniyle 1 hafta sonra tabucu edilebilmiștir.

Sonuç: UAE miyomu olan hastalarda giderek artar sıklıkta kullanılmakta olan öncelikle tercih edilmesi gereken alternatif bir tedavi yöntemi olup histerektomiye göre çok daha az invaziv olması, işlem sonrası hastanede yatış gerektirmemesi ve basit sedasyon ya da spinal anestezi altında yapılabilir olması ile önemli alternatif bir seçenektir.

Anahtar kelimeler: miyom, embolizasyon, uterin arter, manyetik rezonans

Corresponding Author:

drcakir1983@gmail.com
C. Cakir 0000-0001-8030-6795

F. Kilinç 0000-0002-7224-7737

A. Erbahçeci Salik 0000-0001-5344-560X H. Selcuk 0000-0001-5606-4423

(c) Telif hakkı Sağlık Bilimleri Üniversitesi Bakırköy Dr. Sadi Konuk Eğitim ve Araştırma Hastanesi'ne aittir. Logos Tıp Yayıncılık tarafindan yayınlanmaktadır. Bu dergide yayınlanan bütün makaleler Creative Commons Atff-GayriTicari 4.0 Uluslararası Lisansı ile lisanslanmıştı.

(c) Copyright Health Sciences University Bakırköy Sadi Konuk Training and Research Hospital. This journal published by Logos Medical Publishing.

Licenced by Creative Commons Attribution-NonCommercial 4.0 International (CC BY-NC 4.0) 


\section{INTRODUCTION}

Uterine fibroids which are known as leiomyomas are the most common gynecological benign neoplasias of the reproductive age, affecting $20-30 \%$ of women in this period ${ }^{(1)}$. Uterine fibroids do not pose a vital threat, but it reduces the quality of life of the patient due to the symptoms patients encountered.

Ultrasonography (US) is the first-line imaging modality for uterine myomas, although it often fails to detect lesions smaller than $1 \mathrm{~cm}$ in diameter. Transvaginal US has greater sensitivity than transabdominal US in detecting uterine leiomyomas. Today computed tomography (CT) is not indicated for imaging uterine fibroids. In consideration of the advantages of magnetic resonance (MR) imaging with regard to detection of myomas, MR can be used to determine number and localization of myomas and even perform volumetric calculations; thus, it is regarded as the best imaging method for uterine leiomyomas. Uterine leiomyosarcoma. uterine contractions, adenomyosis, adnexal masses are pathologies to be considered in differential diagnosis.

The aim of treatment is to prevent complications that may occur due to fibroids, and to improve the patient's quality of life. Medical treatment, hysterectomy, myomectomy and embolization are methods used in the treatment of fibroids. Uterine artery embolization (UAE), which is a minimally invasive method, can be performed with intravenous sedation, spinal anesthesia or local anesthesia. Many studies have shown that UAE has become an important option in relieving the symptoms that occur by decreasing the fibroid volume and thereby increasing the quality of life of patients ${ }^{(2)}$. UAE is a safe treatment method that can be applied by invasive radiologists during angiography, and the aim of this study was to evaluate the effectiveness of uterine artery embolization.

\section{MATERIALS and METHODS}

The study was planned as a single-center retrospective study and included 40 patients who had undergone UAE procedure, and presented to our clinic between February 2017 and July 2019 due to symptoms (less frequent urination, bleeding, anemia, abdominal pain and palpable mass) associated with uterine leiomyoma.

Patients who had uterine leiomyoma but did not have complaints associated with myoma such as bleeding, anemia, frequent urination, and abdominal pain and a asymptomatic course were not included in the study.

In addition, intracavitary myoma, broad-ligament myoma and cervical myoma, determined on MRI were not deemed to be suitable localizations for $U A E$, and therefore patients with myoma in these localizations were excluded from the study. In the current study patient group, the myomas were in intramural, subserous, submucous or multiple localizations.

All patients provided informed consent for UAE procedure. For all patients, MR images, clinical symptoms experienced were scanned before UAE procedure and at the 6th month after the procedure and digital subtraction angiography (DSA) images were obtained retrospectively from patient files, computerized recording systems, and imaging archives.

MRI scans were performed using pelvic superficial coils in a $3 T$ (Tesla) MRI device (Siemens Verio, Malvern, PA, US). Pelvic MR scans included T2W sagittal and axial; T1W sagittal, axial, and coronal; and post-i.v. 15 cc Gadobutrol injection T1W sagittal, axial, and coronal sequences. Volumes of leiomyomas were calculated based on sagittal and axial images with the formula: height $\mathrm{x}$ width $\mathrm{x}$ length $\mathrm{x} \pi / 6$. In cases having multiple myomas, total myoma volume was calculated by adding the volume of each myoma.

For the embolization procedure, 8 cases received spinal anesthesia and 32 cases sedatives as perioperative analgesia. Foley catheter was inserted in all patients before the procedure, and the foley catheter was filled with $3 / 4$ iodine contrast material and $1 / 4$ saline solution. In addition, IV hydration was applied during procedure to ensure the elimination of the contrast agent.

Afterwards UAE procedures were performed under fluoroscopic (Allura FD 20/20, PhilipsMedicalSystem, Best, Netherlands) guidance. For the procedure, a 5 
French (Fr) arterial sheath was placed in the right common femoral artery under ultrasonographic guidance. Then, internal iliac arteries were selectively catheterized using Kobra diagnostic catheter (5 Fr) [Cordis, Johnson and Johnson, USA] for the left uterine artery and Simmon 1 diagnostic catheter (5 Fr) [Cordis, Johnson and Johnson, USA] for the right uterine artery. Distal embolization was achieved using microsphereagents (Embosphere Microspheres; MeritMedical, USA) with sizes varying between 500700 microns and 700-900 microns and with super selective catheterization of central and peripheral branches of uterine artery by inserting 2.8 Fr Rebar 27 (Medtronic, Irvine [CL], USA) or 2.8 Fr EmboCath Plus (BiosphereMedical, France) microcatheter through the existing diagnostic catheter in ipsilateral oblique projection. Dyeing for myoma disappeared in control angiograms after embolization, and this was accepted as complete embolization. None of the patients developed any complications associated with the endovascular procedure.

Foley catheter was removed following the procedure, and patients received i.v. analgesics until the 6th post-op hour. All patients received ciprofloxacin $500 \mathrm{mg}$ peroral twice daily and nonsteroid anti-inflammatory medication and proton pump inhibitors for 10 days.

\section{Statistical Analysis}

Frequency and percentage values were given for categorical variables. Mean, standard deviation, median, minimum and maximum values were given for continuous variables. The normal distribution of continuous variables was tested by the KolmogorovSmirnov test. Mann-Whitney $U$ test was used for comparison of two independent groups and KruskalWallis $\mathrm{H}$ test for comparisons of more than two groups. For intergroup comparisons of independent variables that could not show normal distribution, Wilcox's sign rank test was used. A $p$ value of $p<0.05$ was considered statistically significant. Statistical analyses of the data obtained in the study were performed using NCSS 11 software (Number Cruncher Statistical System, 2017 Statistical Software).

\section{RESULTS}

In the present study, a total of 40 patients under- went UAE procedure due to symptoms associated with uterine fibroids. One of the patients had a history of hysterectomy. Patient ages ranged between 23-50 years (mean: 41.23).

All the patients included in the study were symptomatic and the most common symptom was uterine bleeding lasting longer than 7 days, i.e. menorrhagia $(80 \%)$, or excessive, long-term bleeding at frequent and irregular intervals, leading to secondary anemia (60\%). Other symptoms included complaints of abdominal pain, palpable mass, and frequent urination in several patients. All patients were offered hysterectomy by the gynecology clinics before referral to our unit, or they were told that hysterectomy may be required during myomectomy.

Medical treatment (GNRH analog) had been previously taken by 12 patients and 1 patient had undergone a myomectomy operation. In the patient histories, there was multiparity in 30 , primaparity in 9, and nulliparity in 1 . case Although myomectomy is known to be recommended when the patient wishes to preserve fertility, there was no expectation of pregnancy in any of the study group patients and no pregnancy was observed during the followup period.

The largest myoma in our series had a volume of $1020 \mathrm{cc}$, and the smallest one had a volume of $17 \mathrm{cc}$. In our series, clinical symptoms, MRI and digital subtraction angiography (DSA) findings were presented. Based on MRI findings mean volumes of uterine fibroids before UAE and 6 months after UAE were $234.47 \pm 76.48$ ccand $117.27 \pm 43.53 \mathrm{cc}$, respectively $(p=0,001)$ and also all parameters were statistically significant (Table 1).

Table 1. MRI findings mean volumes of uterine fibroids before UAE and 6 months after UAE.

\begin{tabular}{cccc}
\hline & $\begin{array}{c}\text { Pre UAE } \\
(\mathbf{n})\end{array}$ & $\begin{array}{c}\text { Post UAE } \\
(\mathbf{n})\end{array}$ & P-value \\
\hline & $\begin{array}{l}\text { Ort.+SS } \\
\text { Med. (Min.-Maks.) } \\
(\mathbf{n}=40)\end{array}$ & $\begin{array}{c}\text { Ort.+SS } \\
\text { Med. (Min.-Maks.) } \\
(\mathbf{n}=40)\end{array}$ & \\
\hline MRI & $234,47 \pm 76,48$ & $117,27 \pm 43,53$ & 0,001 \\
& $193-(17-1020)$ & $90-(4-810)$ & \\
\hline
\end{tabular}

MRI $(p=0.001, p<0.05)$, the pre-median value was found to be statistically significantly higher than the post value. 
Examination of mean and median values estimated before and after UAE procedure showed that the procedure resulted in reduction in the volume of myoma (Graphic 1). In addition to changes in myoma volume, decreased signal intensity on T2A images, and changes in contrast enhancement in myoma on pelvic MRI.were also analyzed. A successful procedure was accepted as presence of $50 \%$ or greater volumetric regression of the size of myoma and decrease in signal intensity of myoma in T2A images with loss or decrease of contrast enhancement in fibroids at the 6-month follow-up MRI. When all these MR parameters were evaluated before and at 6th months after the UAE procedure, the desired result was seen to have been achieved and the procedure was accepted as successful in all 39 patients.

Embolization was performed unilaterally due to intense atherosclerotic lesions in one patient, so, an unsuccessful procedure was accepted as presence of $50 \%$ smaller volumetric regression of the myoma at the 6-month follow-up MRI. The remaining 39 patients underwent successful bilateral UAE procedure. There were no complications associated with endovascular procedure. After the procedure a total of 39 patients were discharged on the same day following bed rest and 1 patients could be discharged 1 week later due to developmentn of urosepsis. The procedure was not repeated in any patient. In the examinations the patient's bleeding and anemia and other described symptoms completely regressed after 6 months.

\section{DISCUSSION}

Myomas are well-circumscribed, benign tumors, which are mainly formed of smooth muscle cells and pseudocapsules with different amounts of fibroconnective tissue. Myomas can be single or multiple, with size varying from just a few millimeters to a volume sufficient to fill the abdomen. As the size increases, urinary incontinence may occur due to bladder compression, and its posterior localisation may cause constipation in the rectosigmoid region $(1,3)$. In literature, the most common complication of fibroids has been reported to be abnormal uterine bleeding ${ }^{(1)}$. Generally, myomas with a submucosal location cause ulceration and degeneration in the endometrium ${ }^{(4)}$.
All the patients in the current series had uterine bleeding, i.e. menometrorrhagia, which is defined in literature as menorrhagia or excessive bleeding at long, frequent and irregular intervals which resulted in chronic anemia in 2 cases, that did not improve despite medical treatment. Hysterectomy and myomectomy are traditional treatment methods for symptomatic myomas ${ }^{(5)}$. In addition to abnormal menstrual bleeding, UAE can be preferred to hysterectomy in cases with evident pain and pressure symptoms, and in patients who did not expect to become pregnant. The standard imaging method of contrast-enhanced pelvic MRI was used in the current study as it shows the uterine zonal anatomy perfectly during evaluation of patients who are to undergo fibroid embolization before the procedure and at the 6-month follow-up examination ${ }^{(6)}$. Myomas are observed on MRI as well-defined masses. On high-resolution, fat-free T2A images taken in three planes they are observed with a significantly lower signal intensity compared to the myometrium and these imaging modalities are therefore the most reliable imaging sequences for the detection of fibroids ${ }^{(7,8)}$. Accompanying pathologies and their amount can also be determined and volumetric calculation can be made. As the sizes increase in myomas, different types of degeneration develop in the process of progression with arterial feeding, and significant deterioration is seen especially in the central section. Non-degenerated myomas consist of smooth muscle cells as well as collagen in different proportions. The reason for the high signal intensity detected on T2A images is that myomas consist of compact smooth muscle cells, and do not contain collagen. They also show marked contrast enhancement due to increased vascularity and intense cellularity, and thus give the best response to UAE treatment ${ }^{(9)}$.

Degenerated myomas have mostly irregularly defined contours, and they are observed with a low signal intensity on T2A images if they contain hyaline and areas of calcifications depending on the content, and may show different signal intensities. In addition, T1A images may show different ratios of contrast enhancement Although degenerated cystic myomas show a high signal on T2A images, they do not uptake contrast material. Myomas with myxoid degeneration show a very high T2A signal intensity with minimal contrast uptake ${ }^{(1)}$. In addition to num- 
ber and signal intensity, intracavitary myoma, broadligament myomas and cervical myomas observed on MRI are not suitable localizations for UAE, and such patients with myoma were excluded from the study. The patient group of the current study comprised patients with myomas located in intramural, subserous, submucous or multiple localizations. Although the submucosal type is less common (approximately $5 \%)$, they are largely symptomatic, as in the current series, and frequently cause dysmenorrhea, menorrhagia and infertility ${ }^{(10)}$. The UAE procedure, which is
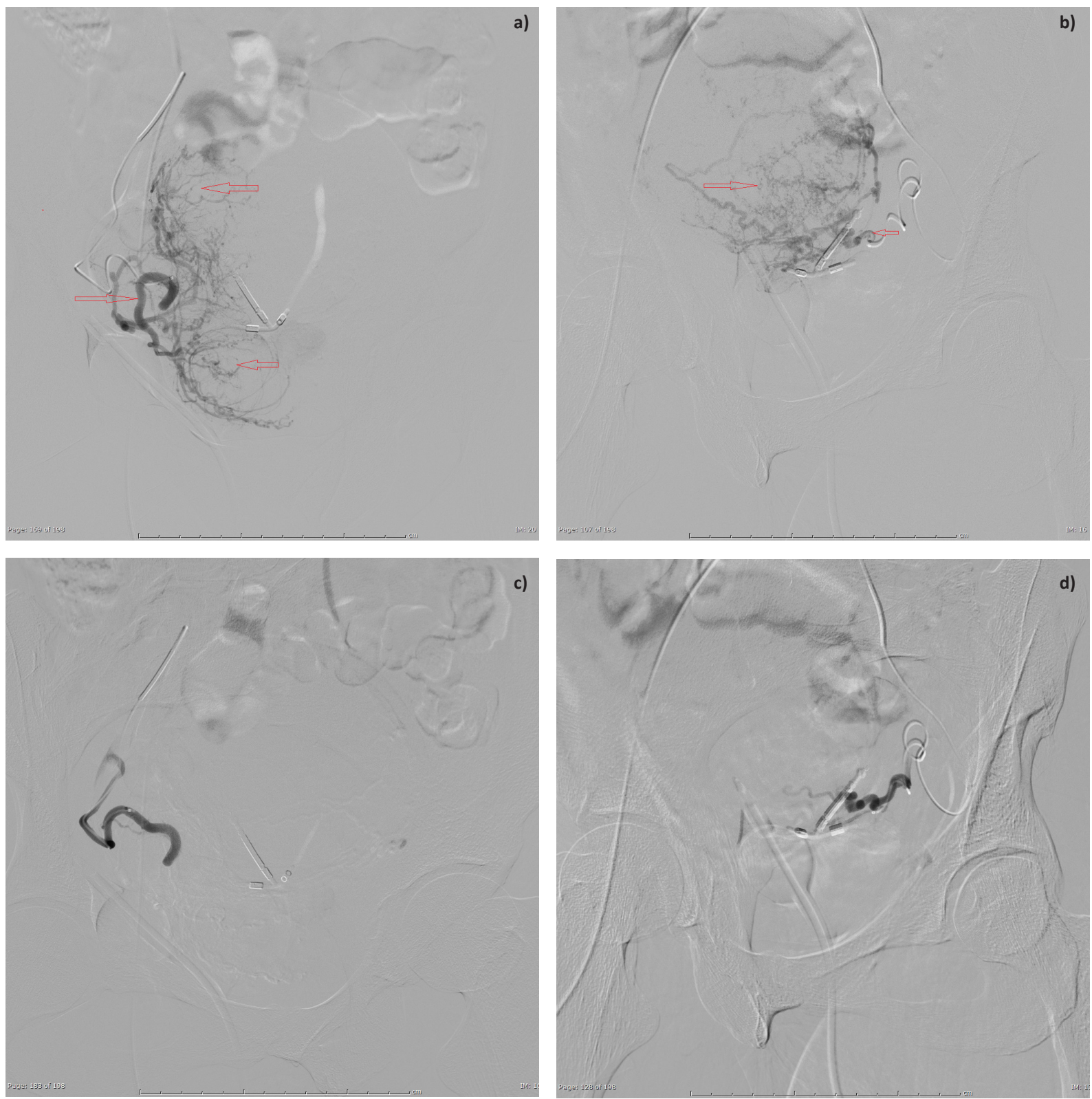

Figure 1. Digital subtraction angiography showing (a) the branches of myomas fed from the right uterine artery (red arrows), (b) the branches of myomas fed from the left uterine artery (red arrows), (c, d) after successful embolization of the uterin artery.. 
materials are the current first choice embolization agents, and these were used in the present series. Distal embolization was achieved in uterine arteries in this study with the use of microspheric agents ranging in size from $500-700$ microns to $700-900$ microns. The UAE procedure was terminated when the myoma stopped bleeding completely and the blood flow was observed to in the uterine artery. All the fibroids had a prominent hypointense signal on T2A contrast images and necrosis was observed on contrast T1A images after successful embolization of the uterine fibroid ${ }^{(9)}$ (Figure 2).

In this series, almost all necrosis was observed with T1A contrast images, and that the persistence of partial contrast enhancement indicates that the procedure had failed and embolization was required in the myomas. A review of the related literature shows varying volumetric reduction rates between $42-83 \%$ following UAE. This rate was $50 \%$ in ur series. Previous studies reported reduction in uterine size by $43-58 \%$ after the procedure. This rate was $51 \%$ in our series ${ }^{(12-15)}$. In the examinations the patient's menorrhagia, menometrotagy and other described symptoms completely regressed after 6 months.

Complications related to the treatment of endovascular embolization in UAE; especially pseudoaneurysm due to vascular injury at the intraducer access site, arterial dissection and arteriovenous fistulas with contrast nephropathy. In addition, off-target embolization should be carefully avoided by preserving the abdominal aorta and cervicovaginal artery branches during the procedure.

Infection, uterine necrosis, pulmonary embolism,
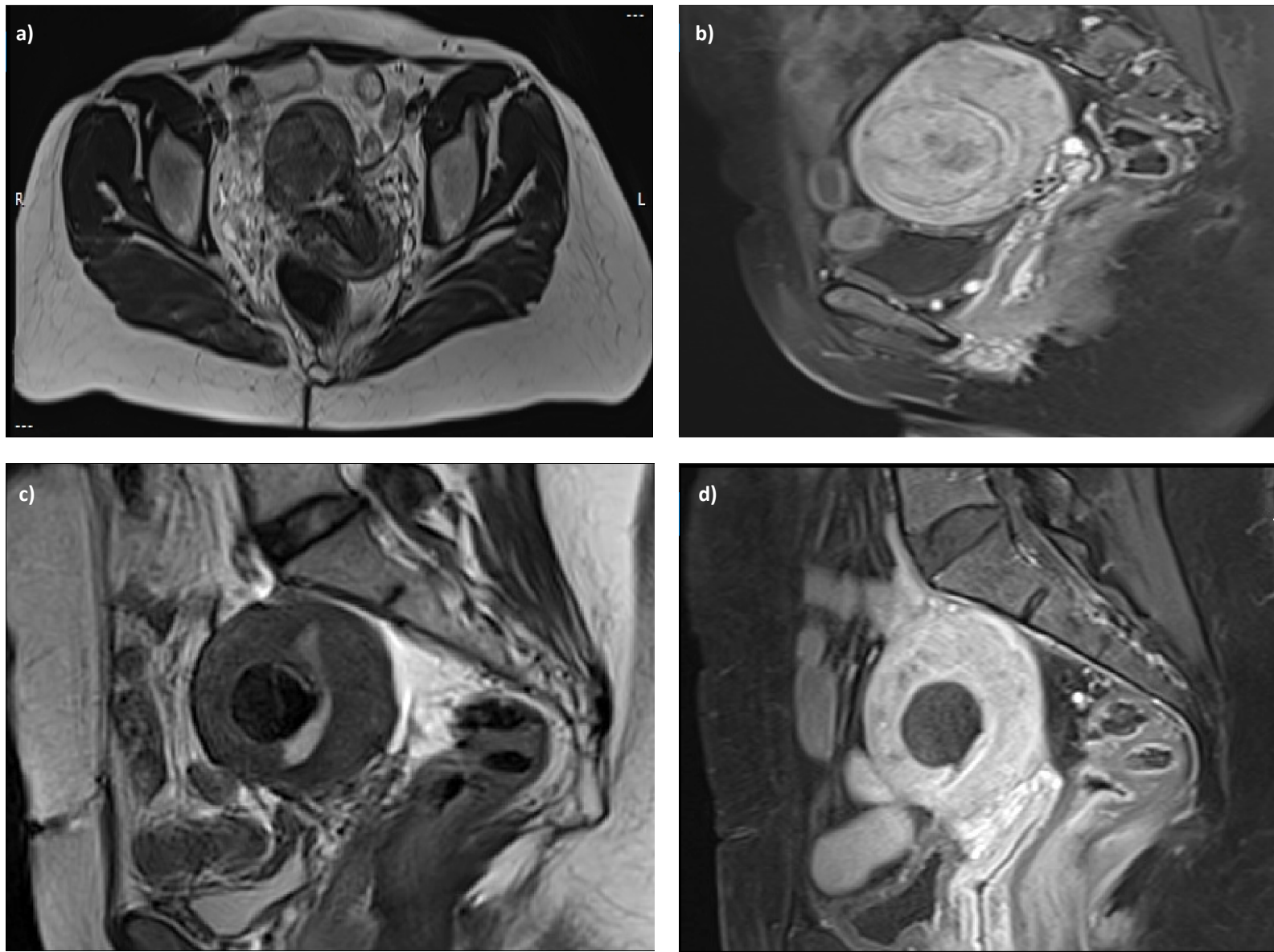

Figure 2. In this case, (a) $58 \mathrm{cc}$ intramural myoma in T2-weighted pelvic MRI in axial viev before embolization of the uterin artery, (b) Fibroid like contrast heterogeneous myometrium in T1-weighted pelvic MRI in axial viev before embolization of the uterin artery and after (c) UAE. T2-weighted pelvic MRI in sagittal Note the significant volumetric reduction of the myoma (22 cc). T1-weighted contrast sagital image (d) with left infarcted areas in the myoma after UAE. 
UAE

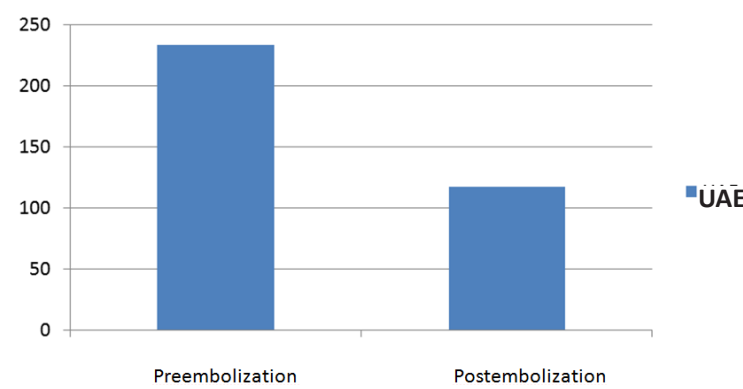

Graphic 1. Uterine Artery Embolization (UAE) procedure showed that the procedure resulted in reduction in the volume of myoma.

and ovarian failure are among the major UAE complications ${ }^{(16-18)}$. In the current study, no major or minor complications were observed in the patient group treated. "Postembolization syndrome", presenting with signs of pelvic pain (uterine cramping), fever, nausea and vomiting was observed ias an an early phase clinical condition after the uterine artery embolization. This clinical condition was tolerated with the administration of IV analgesia, which lasted for up to twenty-four hours postoperatively. The rate of surgical complications of hysterectomy increases especially as the fibroid volume increases. Compared to the high morbidity rate of open hysterectomy, which causes a very high amount of bleeding during surgery and requires intensive care after the procedure, UAE is a less invasive method. UAE is a technically easy procedure, and if applied by experienced centers, it may be considered as a safe treatment method for a young patient group with variations in pelvic vascular anatomy, as in the current series. Superselective catheterization and embolization of bilateral uterine artery with DSA in patients with symptomatic myomas is a minimally invasive, successful and effective method, and the technical success and early follow-up findings of the current study are similar to those of previous reports in literature.

Ethics Committee Approval: Bakırköy Dr. Approval was obtained from Sadi Konuk Training and Research Hospital Clinical Research Ethics Committee (2019/400, 02.09.2019).

Conflict of interests: The authors declare that they have no conflict interests.

Funding: We wish to confirm that there are no known conflicts of interest associated with this publication and there has been no significant financial support and funding for this work that could have influenced its outcome.

Informed Consent: Additional informed consent was obtained from all individual participants for whom identifying information is included in this article.

\section{REFERENCES}

1. Murase E, Siegelman ES, Outwater EK, Perez-Jaffe LA, Tureck RW. Uterine leiomyomas: histopathologic faeatures, MR imaging fndings, differential diagnosis, and treatment. Radiographics. 1999;19(5):1179-97.

https://doi.org/10.1148/radiographics.19.5.g99se131179

2. Lohle PN, Voogt MJ, De Vries J, et al. Long-term outcome of uterine artery embolization for symptomatic uterine leiomyomas. J Vasc Interv Radiol. 2008;19(3):319-26. https://doi.org/10.1016/j.jvir.2007.10.011

3. Buttram VC Jr. Uterine leiomyomata-aetiology, symptomatology and management. Prog Clin Biol Res. 1986;225:275-96.

4. Creasman WT. Disorders of the uterine corpus. In: Scott JR, DiSaia PJ, Hammond CB, Spellacy WN, editors. Danforth's obstetrics and gynecology. Philadelphia: Lipincott; 1994. p. 925-55.

5. Tomislav S, Josip M, Liana CS, et al. Uterine artery embolization as nonsurgical treatment of uterine myomas. ISRN Obstet Gynecol. 2011;2011:489281. https://doi.org/10.5402/2011/489281

6. Voogt MJ, Arntz MJ, Lohle PNM, Mali WPM, Lampmann LEH. Uterine fibroid embolisation for symptomatic uterine fibroids: a survey of clinical practice in Europe. Cardiovasc Intervent Radiol. 2011;34(4):765-73. https://doi.org/10.1007/s00270-010-9978-8

7. Hamlin DJ, Pettersson H, Fitzsimmons J, Morgan LS. MR imaging of uterine leiomyomas and theircomplications. J Comput Assist Tomogr. 1985;9:902-7. https://doi.org/10.1097/00004728-198509000-00012

8. Riccio TJ, Adams HG, Munzing DE, Mattrey RF. Magnetic resonance imaging as an adjunct to sonography in the evaluation of the female pelvis. Magn Reson Imaging. 1990;8(6):699-704. https://doi.org/10.1016/0730-725X(90)90004-L

9. Chang S, Kim MD, Lee M, Lee MS, Park S, Won JY, et al. Uterine artery embolization for symptomatic fibroids with high signal intensity on T2-weighted MR imaging. Korean J Radiol. 2012;13(5):618-24. https://doi.org/10.3348/kjr.2012.13.5.618

10. Corson SL. Hysteroscopic diagnosis and operative therapy of submucous myoma. Obstet Gynecol Clin North Am. 1995;22(4):739-55.

11. Stampfl U, Radeleff B, Sommer C, et al. Midterm results of uterine artery embolization using narrow-size calibrated embozene microspheres. Cardiovasc Intervent Radiol. 2011;34(2):295-305. https://doi.org/10.1007/s00270-010-9986-8

12. Spielmann A, Keogh C, Forster B, Martin ML, Machan LS. Comparison of $\mathrm{MRI}$ and sonography in the preliminary evaluation for fbroid embolization. AJR Am J Roentgenol. 2006;187(6):1499-504. https://doi.org/10.2214/AJR.05.1476

13. Stewart EA, Rabinovici J, Tempany CM, Inbar $Y$, Regan L, Gostout B, et al. Clinical outcomes of focused ultrasound surgery for the treatment of uterine fibroids. Fertil Steril. 2006;85(1):22-9. https://doi.org/10.1016/j.fertnstert.2005.04.072

14. Helmberger T, Jakobs TF, Reiser MF. Embolization of uterine fibroids. Abdom Imaging. 2004;29(2):267-77. https://doi.org/10.1007/s00261-003-0075-1 
15. Moss JG, Cooper KG, Khaund A, Murray LS, Murray GD, Wu O, et al. Randomised comparison of uterine artery embolization (UAE) with surgical treatment in patients with symptomatic uterine fibroids (REST trial): 5-year results. BJOG. 2011;118(8):936-44.

https://doi.org/10.1111/j.1471-0528.2011.02952.x

16. Kitamura Y, Ascher SM, Cooper C, Allison SJ, Jha RC, Flick PA et al. Imaging manifestations complications associated with uterine artery embolization. Radiographics. 2005;25 Suppl 1:S119-32.

https://doi.org/10.1148/rg.25si055518

17. Torigian DA, Siegelman ES, Terhune KP, Butts SF, Blasco L,
Shlansky-Goldberg RD. MRI of uterine necrosis After uterine artery embolization for treatment of uterine leiomyomata. AJR Am J Roentgenol. 2005;184(2):555-9. https://doi.org/10.2214/ajr.184.2.01840555

18. Dutton S, Hirst A, McPherson K, Nicholson T, Maresh M. A UK multicentre retrospective cohort study comparing hysterectomy and uterine artery embolisation for the treatment of symptomatic uterine fbroids (HOPEFUL study): main results on medium-term safety and effcacy. BJOG. 2007;114(11):1340-51

https://doi.org/10.1111/j.1471-0528.2007.01526.x 